\title{
Efficacy of concomitant and adjuvant temozolomide in glioblastoma treatment. A multicentre randomized study
}

\section{Skuteczność skojarzonego i wspomagajacego leczenia temozolomidem u chorych z glejakiem wielopostaciowym. Wieloośrodkowe badanie z randomizacja}

\author{
Dariusz Szczepanek', Andrzej Marchel2², Marek Moskała ${ }^{3}$, Mariusz Krupa ${ }^{3}$, Przemysław Kunert'², Tomasz Trojanowski'
}

${ }^{1}$ Katedra i Klinika Neurochirurgii i Neurochirurgii Dziecięcej, Uniwersytet Medyczny w Lublinie

${ }^{2}$ Katedra i Klinika Neurochirurgii, Warszawski Uniwersytet Medyczny

${ }^{3}$ Katedra i Klinika Neurochirurgii, Collegium Medicum, Uniwersytet Jagielloński w Krakowie

Neurologia i Neurochirurgia Polska 2013; 47, 2: 101-108

DOI: 10.5114/ninp.2013.34398

\begin{abstract}
Background and purpose: The common treatment in patients with newly diagnosed glioblastoma multiforme is the ultimately radical surgical removal of the tumour combined with radiotherapy. This study compared safety and efficacy of radiotherapy alone with radiotherapy combined with temozolomide (TMZ) given before, during, and after radiotherapy.

Material and methods: The patients operated on for glioblastoma multiforme during the first 21 postoperative days were randomly assigned to the group treated with radiotherapy alone (involved-field radiotherapy in $2 \mathrm{~Gy}$ fractions daily five times a week up to the total of 60 Gy over 6 weeks of treatment) or to the group treated with radiotherapy and TMZ, initially in the dose of $200 \mathrm{mg} / \mathrm{m}^{2}$ during 5 postoperative days and after 23 days followed by $75 \mathrm{mg} / \mathrm{m}^{2}$ of body surface area daily, 7 days a week (from the first to the last day of radiotherapy). On completion of radiotherapy, five complementary courses of TMZ were introduced $\left(150-200 \mathrm{mg} / \mathrm{m}^{2}\right.$ for 5 days, repeated every 28 days). The primary outcome measure was overall survival. Results: Fifty-eight patients from 3 centres were included in the study. The mean age of patients was 55 years and all the patients underwent a surgical procedure of glioblastoma removal. The mean overall survival in the group treated with TMZ was 16.0 months, whereas in the group with radiotherapy alone the overall survival reached 12.5 months. 24-month
\end{abstract}

\section{Streszczenie}

Wstęp i cel pracy: $U$ chorych z nowo rozpoznanymi glejakami wielopostaciowymi ogólnie przyjętym postępowaniem jest maksymalnie radykalne operacyjne usunięcie guza uzupełnione napromienianiem. W przedstawionym badaniu porównywano radioterapię jako jedyną metodę leczenia $\mathrm{z}$ radioterapią skojarzona z temozolomidem podawanym przed napromienianiem, w jego trakcie i po zakończeniu radioterapii, oceniając bezpieczeństwo i skuteczność obu metod terapeutycznych. Materiał i metody: Pacjentów operowanych z powodu glejaka wielopostaciowego w ciąu 21 dni po zabiegu przydzielano losowo do grupy, w której stosowano wyłącznie radioterapię (napromienianie na pola wydzielone we frakcjach po 2 Gy dziennie 5 razy w tygodniu do całkowitej dawki 60 Gy w ciągu 6 tygodni leczenia), lub grupy leczonej napromienianiem $\mathrm{i}$ temozolomidem, początkowo $\mathrm{w}$ okresie pooperacyjnym $200 \mathrm{mg} / \mathrm{m}^{2}$ przez $5 \mathrm{dni}$, następnie po 23 dniach dawką $75 \mathrm{mg} / \mathrm{m}^{2}$ powierzchni ciała dziennie przez $7 \mathrm{dni}$ w tygodniu (od pierwszego do ostatniego dnia radioterapii). Po zakończeniu napromieniania prowadzono pięć uzupełniających kursów leczenia temozolomidem $\left(150-200 \mathrm{mg} / \mathrm{m}^{2}\right.$ przez $5 \mathrm{dni}$ powtarzanymi co 28 dni). Główną miarą wyniku leczenia był całkowity czas przeżycia.

Wyniki: Do badania włączono 58 chorych z 3 ośrodków. Mediana wieku pacjentów wynosiła 55 lat, wszyscy chorzy byli

Correspondence address: Dariusz Szczepanek, Katedra i Klinika Neurochirurgii i Neurochirurgii Dziecięcej, ul. Jaczewskiego 8, 20-954 Lublin, e-mail: dariusz.szczepanek@am.lublin.pl

Received: 22.01.2012; accepted: 30.04.2012 
survival reached $23 \%$ in patients treated with TMZ and $6.7 \%$ in those who received radiotherapy only. Haematological complications of third or fourth degree were present in $10 \%$ of patients treated with radiotherapy and TMZ.

Conclusions: The introduction of TMZ before, during and after radiotherapy for newly diagnosed glioblastoma multiforme gives clinically and statistically significant improvement of survival with unremarkably increased toxicity of the treatment.

Key words: brain tumour, glioblastoma, temozolomide, radiotherapy.

\section{Introduction}

High-grade gliomas - glioblastoma multiforme and anaplastic astrocytoma - account for more than $20 \%$ of brain tumours in adults. According to current knowledge, median time of survival after diagnosis does not exceed 12 months, and even in the presence of favourable outcome predictors, most patients die within 24 months [1-3].

The current standard of care involves maximally radical surgical excision of the tumour followed by postoperative radiotherapy. Various forms of chemotherapy combined with surgery and radiotherapy are used in case of recurrence or in clinical trials. So far, adjuvant chemotherapy has not shown unequivocal improvement of the efficacy of treatment in comparison to the standard therapy that combines surgery and radiotherapy. Despite the advances in surgical techniques, introduction of new methods of radiotherapy and various chemotherapeutic regimens, the prognosis in high-grade gliomas remains poor, and the improvement of survival after chemotherapy is modest $[2,4-6]$.

There is an ongoing search for new chemotherapy and radiotherapy methods that might improve the efficacy of treatment in those neoplasms $[2,7]$.

Recently, temozolomide (TMZ) has been introduced to clinical use as a method of treatment in glia-derived brain neoplasms $[2,7,8]$.

Clinical trials conducted in many departments assessed various chemotherapy regimens combined with radiotherapy. None of the phase III randomized trials that assessed the efficacy of nitrosourea-derived compounds as adjuvant therapy showed substantial improve- operowani z powodu glejaka wielopostaciowego. Mediana czasu przeżycia w grupie otrzymującej temozolomid wyniosła 16 miesięcy, natomiast wśród otrzymujących radioterapię 12,5 miesiąca. Przeżycie 24-miesięczne osób w grupie skojarzonego leczenia wyniosło $23 \%$, natomiast w ramieniu kontrolnym $-6,7 \%$. Powikłania hematologiczne 3. lub 4. stopnia pojawiły się u $10 \%$ otrzymujących radioterapię łącznie z temozolomidem.

Wnioski: Podawanie temozolomidu przed radioterapią, w jej trakcie i po radioterapii u chorych na nowo rozpoznanego glejaka wielopostaciowego w istotny klinicznie i statystycznie sposób wydłuża przeżycie przy niewielkim zwiększeniu toksyczności leczenia.

Słowa kluczowe: guz mózgu, glejak wielopostaciowy, temozolomid, radioterapia.

ment of the long-term survival when compared with radiotherapy alone as the only adjuvant treatment after surgery [9]. Several studies showed a higher percentage of long-term survival in patients who received additional chemotherapy $[10,11]$.

Temozolomide is an oral alkylating agent, a derivative of imidazotetrazine with a broad spectrum of antineoplastic activity. So far, TMZ has been shown to be efficacious in the treatment of patients with glioblastoma recurrence, in whom other therapies have failed [12]. Both theoretical and clinical presumptions suggest that the use of that drug in the early phase of treatment, when the vascularization of the tumour is not compromised, bioavailability is adequate, and chemo-resistance does not occur, might improve the efficacy of treatment. Therefore, the concomitant use of TMZ and radiotherapy may decrease the number of active clonogenic cells more efficiently than any of those methods alone. Synergic action of radiotherapy and TMZ was shown in experiments performed with human glioma cell cultures. It might be expected that the use of radiotherapy and TMZ may delay the recurrence and prolong the progression-free period.

Preliminary reports suggest that the use of TMZ (200 mg/m² of body-surface area daily for five days, each 28 days) before radiotherapy in 33 patients with malignant gliomas not suitable for surgery or partially resected led to a positive response to therapy in 17 patients (52\%). A previous publication reported a positive response after the treatment in $30 \%$ of patients. Moreover, the chemotherapy applied directly after surgery might be more efficacious than the same treatment used in case of recurrence, because it acts on a smaller volume of the tumour. 
So far, the TMZ regimen has included the use of $150-200 \mathrm{mg} / \mathrm{m}^{2}$ for five consecutive days in cycles repeated every 28 days. Some centres adopted quite a safe regimen of daily therapy with TMZ given in the dose of $75 \mathrm{mg} / \mathrm{m}^{2}$ up to 7 weeks $[7,13]$. The abovementioned concentration of the drug [14] substantially inhibits the activity of $\mathrm{O}^{6}$-methylguanine-DNA methyltransferase (MGMT), the enzyme involved in DNA repair [15]. This situation might be important, because of the reported association between low activity of MGMT in tumour cells and the longer survival of patients with glioblastoma multiforme treated with additional regimens of chemotherapy with nitrosourea derivatives $[16,17]$.

\section{Material and methods}

\section{Patients}

This study included patients aged between 17 and 70 with newly diagnosed and histopathologically confirmed glioblastoma multiforme (World Health Organization [WHO] grade IV). Neuropathological examination was required for all patients. The definite histopathological diagnosis was established centrally by a single neuropathologist.

Other inclusion criteria consisted of the surgical removal of the tumour (regardless of the extent of the resection), time from surgery to randomization (after histopathological confirmation of the diagnosis) $<21$ days, age between 17 and 70, WHO performance scale $\leq 2$, and Karnofsky scale $>60$. Patients could not be treated with corticosteroids within 14 days before randomization, and could not receive radiotherapy and/or chemotherapy previously. The results of biochemical studies (complete blood count, renal function, liver function) assessed within 14 days before randomization should be normal. The required values of the laboratory studies were as follows: total neutrophil count $\geq 1.5 \times 10^{9} / \mathrm{L}$; platelet count $\geq 100 \times 10^{9} / \mathrm{L}$, serum creatinine $\leq 1.5$ times the upper limit of normal for the laboratory, total serum bilirubin $\leq 1.5$ times the upper limit of normal for the laboratory, AST or ALT $<2.5$ times the upper limit of normal for the laboratory, and alkaline phosphatase $<2.5$ times the upper limit of normal for the laboratory.

Exclusion criteria consisted of chronic viral hepatitis $\mathrm{B}$ or hepatitis $\mathrm{C}$ virus infection, disorders potentially affecting the oral ingestion of the medication, e.g. common vomiting, partial ileus, concomitant or previous malignancy, except for surgically cured carcinoma in situ of the cervix or skin. Pregnancy in women at childbear- ing age was excluded with urine-based pregnancy tests or with serum beta-human chorionic gonadotropin measurements within 72 hours after randomization.

The patient's informed consent for the treatment within the clinical trial conditions was required before randomization. All patients signed the informed consent for participation in the study, and the study protocol was approved by the ethical committee of each participating centre.

\section{Study design and treatment}

Patients who fulfilled the criteria were randomly assigned at a $1: 1$ ratio either to radiotherapy alone or to TMZ and radiotherapy. Randomization was performed in the Department of Neurosurgery and Paediatric Neurosurgery in Lublin. Treatment ought to start within the week after randomization (Fig. 1).

\section{Radiotherapy}

Conventionally fractionated external beam radiotherapy starting between 44 and 74 days after surgery
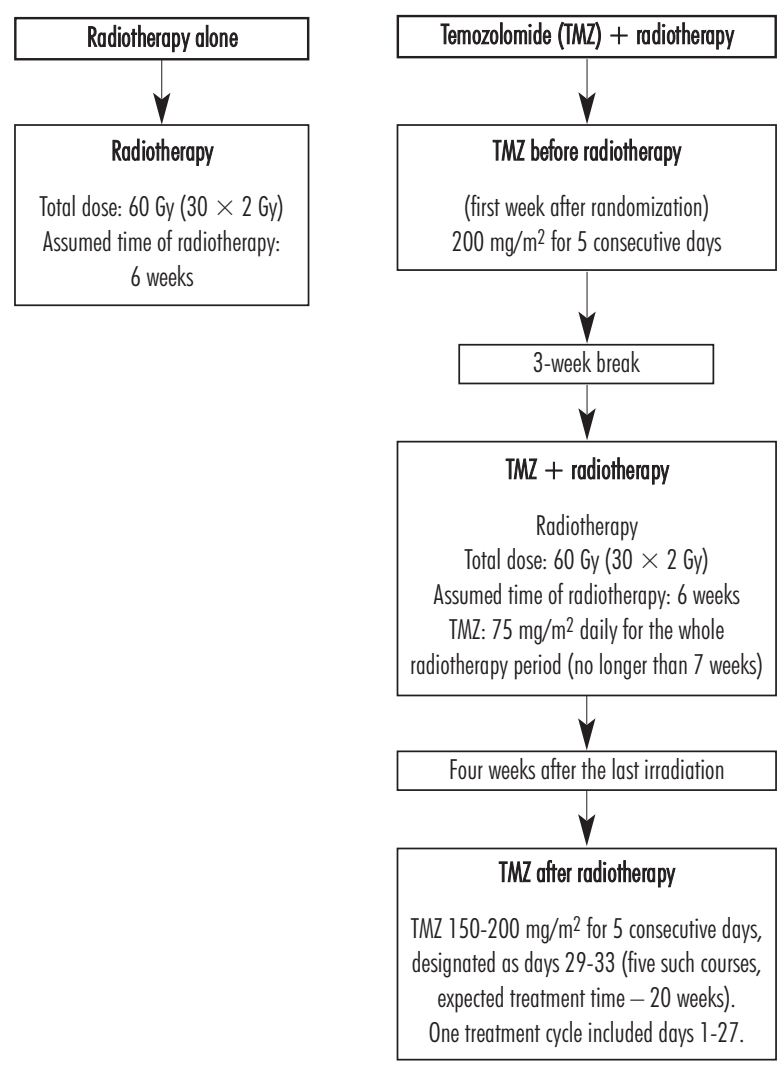

Fig. 1. Patients' treatment 
(2 Gy per fraction) was applied five times a week for 6 weeks to the total dose of $60 \mathrm{~Gy}(30 \times 2 \mathrm{~Gy})$. Radiotherapy was applied using three-dimensional planning techniques, and with megavolt apparatus; the dose was specified according to the ICRU 50 (International Commission of Radiation Units and Measurements) recommendations. Radiotherapy required linear accelerators generating $\mathrm{X}$ photons at the lowest nominal energy of $4 \mathrm{MV}$. Dose rate at the reference point was at least $0.5 \mathrm{~Gy}$ $\times$ min $^{-1}$. Only one planning target volume (PTV) was used during one cycle of radiotherapy. PTV was determined according to the results of preoperative computed tomography (CT) or magnetic resonance imaging (MRI). PTV had to involve the tumour volume enhancing after contrast injection and 2-to-3-cm margins.

In patients with gross total excision and dislocation of the tumour bed in relation to the preoperative imaging, the location of the tumour bed was indicated by the site investigators according to their experience, with 2-3-cm margins. The high-dose area could not involve eye-balls, optic nerves, optic chiasm, nasopharynx or auditory canals.

\section{Treatment with temozolomide}

After allocation to treatment with $\mathrm{TMZ}$ and radiotherapy, TMZ was given for five consecutive days (200 mg/ $\mathrm{m}^{2}$ ) in the week following randomization. After three weeks, TMZ was given orally $\left(75 \mathrm{mg} / \mathrm{m}^{2}\right)$ daily for 6 weeks, starting on the day when the radiotherapy had begun. Then, four weeks after the last radiotherapy fraction, TMZ was continued daily in 5-day cycles (first cycle: $150 \mathrm{mg} / \mathrm{m}^{2}$; next cycles: $200 \mathrm{mg} / \mathrm{m}^{2}$ ) every four weeks for five cycles. Antiemetic prophylaxis with $5-\mathrm{HT}_{3}$ antagonists was recommended before the first dose of TMZ. Antiemetic prophylaxis with $5-\mathrm{HT}_{3}$ antagonists was used quite rarely during the treatment with low-dose TMZ concomitant to the radiotherapy. The prophylaxis of pneumonia due to Pneumocystis carinii infection was required in all patients treated with TMZ during radiotherapy. The complete blood count was required within 72 hours before radio- and chemotherapy. The treatment could be initiated if the total neutrophil count was at least $1.5 \times 10^{9} / \mathrm{L}$, and the platelet count was at least $100 \times$ $10^{9} / \mathrm{L}$. The daily dose of TMZ was $75 \mathrm{mg} / \mathrm{m}^{2}$.

The severity of chemotherapy-related complications was assessed according to the National Cancer Institute Common Toxicity Criteria, in which the severity of adverse events was rated as: 1 - mild, 2 - moderate, 3 - severe, and 4 - life-threatening. The complete blood count had to be obtained 21 days ( \pm 47 hours) after the first dose of each maintenance cycle. The most common adverse events related to treatment with TMZ include haematological toxicity (leukopenia, lymphopenia, thrombocytopenia and anaemia), nausea and vomiting, renal failure, abnormal activity of liver enzymes, somnolence, rash, constipation, fatigue, anorexia, hyperglycaemia, and diarrhoea.

Patients receiving radiotherapy were examined by the physician once a week. Stage assessment was required at the fourth week (day 21-27) after the beginning of radiotherapy. Patients receiving TMZ concomitantly to radiotherapy were assessed once a week for four weeks after the end of radiotherapy. Assessment consisted of history-taking and complete blood count evaluation. The next assessment was performed 21-27 days after the end of radiotherapy (given alone or with TMZ). During the follow-up and during the adjunctive treatment with TMZ, monthly visits were recommended. The same schema of the clinical assessment was used in both treatment arms. Clinical evaluation within this study was required in the following periods: the fourth week (day 21-27) after the last chemotherapy session and every three months until death. The evaluation consisted of physical (including neurological) examination, $\mathrm{WHO} / \mathrm{ECOG}$ performance status, Mini-Mental State Examination, quality of life questionnaire, MRI or CT (two years after the surgery, the frequency of imaging studies was left at the discretion of the investigator; the assessment schema had to be the same in both treatment arms). Corticosteroids were given according to the recommendations of the treating physician. The use of granulocyte colony stimulating factor for the increase of neutrophil count was not allowed. The use of erythropoietin was not contraindicated. No other drug currently being tested in clinical trials was allowed. Surgical decompression (osteoclastic craniotomy), other forms of chemotherapy, immunotherapy or biological therapy could not be applied. Neither stereotactic radiotherapy nor brachytherapy could be planned. If such treatment was necessary, the patient would not receive further treatment with TMZ according to the protocol of the study. In case of tumour progression, the decision on further management was made by the treating physician.

\section{Evaluation methods}

The main outcome measure was the time of overall survival. The other assessed outcomes included progression-free survival, rates of survival after 6, 12, 18 and 24 months, safety of treatment and the quality of life. Survival time was the interval between the date of the 
surgery and death. Progression was diagnosed when clinical symptoms and signs of progression occurred (worsening of neurological status) and the imaging (CT or MRI) showed an increase of the volume of the tumour $>25 \%$. The progression-free period was defined as the interval between the date of the surgery and either the diagnosis of progression or death. Occurrence and severity of toxicity were compared using the Kruskal-Wallis test. Analysis of treatment toxicity was performed separately for the first stage of chemotherapy, just before the beginning of radiotherapy, for radiotherapy alone (up to the $28^{\text {th }}$ day after the last radiotherapy session or to the first day of therapy with TMZ), as well as for adjuvant therapies. Adverse events of radiotherapy were assessed 4 weeks after the last radiotherapy session and graded according to the Common Toxicity Criteria (CTC) system.

Haematological disturbances were assessed according to the complete blood count test performed weekly. Nadir was calculated for each treatment cycle and graded according to the CTC scale. Non-haematological adverse events were assessed and registered separately for each treatment cycle and graded according to the CTC scale.

\section{Results}

\section{Patients}

The first patient was randomized on 26 October 2003 , and the last patient was randomized on 30 September 2005. Lublin centre recruited 37 patients (including 21 treated with TMZ), Warsaw centre recruited 13 patients (including 4 treated with TMZ), and Krakow centre recruited 8 patients (including 3 treated with TMZ). Patients were randomly assigned to treatment with radiotherapy only $(n=28)$ or radiotherapy combined with TMZ $(n=30)$. The baseline characteristics of patients in both groups before treatment were similar (Table 1).

Median age was 55 years. At the time of randomization, patients did not receive corticosteroids. The diagnosis of glioblastoma multiforme was confirmed in 58 patients.

\section{Patients' disposition and treatment characteristics}

Median time from randomization to the first course of TMZ before radiotherapy was 7 days (range, 1-14). Median time from randomization to the onset of radiotherapy was 43 days (range, 33-62). Interruptions dur-
Table 1. Baseline characteristics of patients

\begin{tabular}{|c|c|c|}
\hline & $\begin{array}{l}\text { Radio- } \\
\text { therapy }\end{array}$ & $\begin{array}{c}\text { Radio- } \\
\text { therapy } \\
+ \text { temozo- } \\
\text { lomide }\end{array}$ \\
\hline Age [years]; median (range) & $56(20-68)$ & $55(18-65)$ \\
\hline \multicolumn{3}{|l|}{ Age group; $n(\%)$} \\
\hline$<50$ years & $5(17)$ & $4(14)$ \\
\hline$>50$ years & $25(83)$ & $24(86)$ \\
\hline \multicolumn{3}{|l|}{$\operatorname{Sex} ; n(\%)$} \\
\hline Men & $16(53)$ & $18(64)$ \\
\hline Women & $14(47)$ & $10(36)$ \\
\hline \multicolumn{3}{|l|}{ Performance status (WHO), $n(\%)$} \\
\hline 0 & $14(47)$ & $11(39)$ \\
\hline 1 & $12(40)$ & $15(54)$ \\
\hline 2 & $2(6)$ & $2(7)$ \\
\hline \multicolumn{3}{|l|}{ Extent of tumour resection; $n(\%)$} \\
\hline Total resection & $18(60)$ & $18(64)$ \\
\hline Partial resection & $12(40)$ & $10(36)$ \\
\hline $\begin{array}{l}\text { Time from randomization to onset } \\
\text { of radiotherapy [days]; median (range) }\end{array}$ & $48(38-65)$ & $43(32-62)$ \\
\hline \multicolumn{3}{|l|}{ Baseline MMSE score; $n(\%)$} \\
\hline 30 & $14(47)$ & $13(46)$ \\
\hline $27-29$ & $12(40)$ & $11(39)$ \\
\hline$<26$ & $3(10)$ & $3(11)$ \\
\hline Unavailable & $1(3)$ & $1(4)$ \\
\hline
\end{tabular}

WHO - World Health Organization; MMSE - Mini-Mental State Examination

ing the radiotherapy were quite brief, and interruptions due to treatment toxicity were noted in $5 \%$ of control arm patients and in $6 \%$ of intervention arm patients.

Fourteen out of the 28 patients completed the full treatment cycle (one chemotherapy course before the radiotherapy, chemotherapy + radiotherapy, and five additional chemotherapy courses). Three patients completed four courses of chemotherapy after radiotherapy, three others finished their treatment after three courses of chemotherapy, and one patient after one course of chemotherapy. Four patients had radiotherapy with chemotherapy only, and three others finished their treatment with the first course of radiotherapy and did not even start the radiotherapy. Median age of patients in this group was 55 years.

After completion of radiotherapy, 21 patients in the TMZ arm (75\%) started adjuvant treatment, and 50\% 
of patients completed one planned full course of adjuvant chemotherapy.

The main reason for abandoning treatment was tumour progression.

In two patients (7\%), the treatment was discontinued due to adverse events, i.e. haematological toxicity. The dose of TMZ was increased to $200 \mathrm{mg} / \mathrm{m}^{2}$ in all patients, starting from the second course of chemotherapy.

\section{Survival and progression}

The follow-up until the last fatality lasted 33 months. All 58 patients died within this period. Median time of overall survival in the combined treatment arm was 16.0 months and was significantly longer than in the control treatment arm (12.5 months, $p<0.05$, Cox F-test). The probability of 24-month survival was $23.1 \%$ in patients receiving TMZ + radiotherapy and $6.7 \%$ in patients treated with radiotherapy alone; 18-month survival was noted in $30.8 \%$ and $23.3 \%$, respectively; 12 -month survival was recorded in $65.4 \%$ and $63.3 \%$, respectively; and 6-month survival was noted in $92.3 \%$ and $86.7 \%$, respectively. Median progression-free time was 7.5 months in patients treated with TMZ + radiotherapy and 5.0 months in patients receiving radiotherapy alone.

\section{Adverse events}

An analysis of adverse events was performed for the entire period of treatment (from inclusion in the study to tumour progression or to the last observation), and separately for the radiotherapy period (with or without TMZ) and for the adjuvant chemotherapy period. No haematological toxicity of third or fourth grade was noted among patients receiving radiotherapy alone.

In patients receiving both $\mathrm{TMZ}$ and radiotherapy, neutropenia of grade 3 or 4 did not occur but thrombocytopenia of grade 3 or 4 was noted in one patient (3\%). Haematological complications of grade 3 or 4 were noted therefore in one patient (3\%). In patients receiving additional courses of TMZ, neutropenia of grade 3 or 4 did not occur but thrombocytopenia of grade 3 or 4 was noted in two patients (7\%). Haematological complications of third or fourth grade were noted therefore in two patients (7\%). Severe infections before, during or after radiotherapy did not occur in any patient in either group.

The most common non-haematological adverse event during the irradiation was moderate or severe generalized weakness and nausea, noted in $10(33 \%)$ patients within the control arm and in 8 (29\%) patients treated with TMZ.

\section{Treatment after the diagnosis of tumour progression}

The treating physician decided on further treatment if tumour progression was diagnosed. The surgery was repeated in $10(36 \%)$ patients treated with radiotherapy and TMZ.

\section{Discussion}

Chemotherapy before or during radiotherapy in patients with malignant gliomas has been studied for several decades. As yet, the efficacy of various modes of chemotherapy has been very limited [18]. Based on good results of the study by Stupp et al. we performed our own examination. The results of our study show that the use of chemotherapy shortly after surgery, and combined radio- and chemotherapy, significantly prolong the survival of patients with newly diagnosed glioblastoma multiforme. The present study included patients with glioblastoma only [8]. After the follow-up longer than three years, the authors noted the more than threefold and clinically meaningful improvement of long-term survival probability $(6.7 \%$ in the radiotherapy alone arm and $23.1 \%$ in patients receiving both radiotherapy and TMZ). This finding is in agreement with the conclusions drawn by Stupp $[7,8,19]$.

The outcome of patients who received radiotherapy alone was better in our study than in other trials $[4,7-9,20]$. It should be noted, however, that our study included patients in good clinical condition only, who did not receive corticosteroids during 14 days before randomization. Such a criterion, according to Stupp's conclusion, might be used to exclude patients with poor prognosis who probably would not benefit from any kind of therapy $[3,7,8]$. Patients who lack methylation of the $M G M T$ promoter might be a group of such poor prognosis [2]. Methylation of the $M G M T$ promoter precludes transcription, i.e. production of MGMT, which may result in the lack of repair in TMZ-alkylated DNA [2], and may therefore lead to greater efficacy of TMZ and longer survival of patients with gliomas. Quite long survival (up to 8 months) after the diagnosis of tumour progression should also be highlighted $[7,8,21]$.

The prolonged survival might reflect either the appropriate inclusion criteria or earlier detection of pro- 
gression due to regularly repeated CT or MRI studies. Small doses of TMZ given on a daily basis enable almost twofold (as compared with the standard schema) increase of the dose intensity without increase of toxicity [14]. Continuous administration of an alkylating agent decreases the activity of MGMT [15], which is an enzyme that may be induced by irradiation and is required for the repair of DNA damage caused by alkylating agents [22].

In vitro studies revealed the synergy between TMZ and radiotherapy $[22,24]$. Spontaneous TMZ conversion to active metabolites, and their ability to cross the blood-brain barrier, favour this kind of treatment. Five courses of adjuvant chemotherapy were added in this study to provide adequate exposure to the drug. Toxicity of the adjuvant chemotherapy could be managed symptomatically. Nausea was treated with standard antiemetics. Marked bone marrow suppression occurred in $3(10 \%)$ patients and led to the premature discontinuation of treatment in one female patient. During a follow-up longer than three years, we did not observe an increased incidence of late adverse events in patients treated according to the studied schema. Late toxicity may be more problematic in patients with gliomas other than glioblastoma, with longer survival $[7,8]$.

\section{Conclusion}

The administration of TMZ before, during and after radiotherapy for newly diagnosed glioblastoma multiforme results in a clinically and statistically significant improvement of survival.

\section{Disclosure}

Authors report no conflict of interest.

\section{References}

1. Curran W.J. Jr., Scott C.B., Horton J., et al. Recursive partitioning analysis of prognostic factors in three Radiation Therapy Oncology Group malignant glioma trials. J Natl Cancer Inst 1993; 85: 704-710.

2. Stupp R., Hegi M.E., Neyns B., et al. Phase I/IIa study of cilengitide and temozolomide with concomitant radiotherapy followed by cilengitide and temozolomide maintenance therapy in patients with newly diagnosed glioblastoma. J Clin Oncol 2010; 28: 2712-2718.

3. Frenel J.S., Botti M., Loussouarn D., et al. Prognostic and predictive factors for gliomas in adults. Bull Cancer 2009; 96: 357-367.
4. Stewart L.A. Chemotherapy in adult high grade glioma: a systematic review and metaanalysis of individual patient data from 12 randomised trials. Lancet 2002; 359: 1011-1018.

5. Nieder C., Mehta M.P., Jalali R. Combined radio- and chemotherapy of brain tumours in adult patients. Clin Oncol ( $R$ Coll Radiol) 2009; 21: 515-524.

6. Croteau D., Mikkelsen T. Adults with newly diagnosed highgrade gliomas. Curr Treat Options Oncol 2001; 2: 507-515.

7. Stupp R., Hegi M.E., Mason W.P., et al. European Organisation for Research and Treatment of Cancer Brain Tumour and Radiation Oncology Groups; National Cancer Institute of Canada Clinical Trials Group. Effects of radiotherapy with concomitant and adjuvant temozolomide versus radiotherapy alone on survival in glioblastoma in a randomised phase III study: 5-year analysis of the EORTC-NCIC trial. Lancet Oncol 2009; 10: 459-466.

8. Stupp R., Mason W., van den Bent M., et al. Radiotherapy plus concomitant and adjuvant temozolomide for glioblastoma. N Engl J Med 2005; 352: 987-996.

9. Medical Research Council Brain Tumor Working Party. Randomized trial of procarbazine, lomustine, and vincristine in the adjuvant treatment of high-grade astrocytoma: a Medical Research Council trial. J Clin Oncol 2001; 19: 509-518.

10. Stupp R., Hegi M.E. Recent developments in the management of malignant glioma. In: Perry M.C. [ed.]. ASCO 2003 educational book. American Society of Clinical Oncology, Alexandria 2003, pp. 779-788.

11. Glas M., Happold C., Rieger J., et al. Long-term survival of patients with glioblastoma treated with radiotherapy and lomustine plus temozolomide. J Clin Oncol 2009; 27: 1257-1261.

12. Stupp R., Gander M., Leyvraz S., et al. Current and future developments in the use of temozolomide for the treatment of brain tumours. Lancet Oncol 2001; 2: 552-560.

13. Kocher M., Frommolt P., Borberg S.K., et al. Randomized study of postoperative radiotherapy and simultaneous temozolomide without adjuvant chemotherapy for glioblastoma. Strahlenther Onkol 2008; 184: 572-579.

14. Brock C.S., Newlands E.S., Wedge S.R., et al. Phase I trial of temozolomide using an extended continuous oral schedule. Cancer Res 1998; 58: 4363-4367.

15. Tolcher A.W., Gerson S.L., Denis L., et al. Marked inactivation of O6-alkylguanine-DNA alkyltransferase activity with protracted temozolomide schedules. Br J Cancer 2003; 88: 1004-1011.

16. Esteller M., Garcia-Foncillas J., Andion E., et al. Inactivation of the DNA-repair gene MGMT and the clinical response of gliomas to alkylating agents. N Engl J Med 2000; 343: 13501354.

17. Hegi M.E., Diserens A.C., Godard S., et al. Clinical trial substantiates the predictive value of O-6-methylguanine-DNA methyltransferase promoter methylation in glioblastoma patients treated with temozolomide. Clin Cancer Res 2004; 10: 1871-1874.

18. Shapiro W.R. Chemotherapy of malignant gliomas: studies of the BTCG. Rev Neurol 1992; 148: 428-434.

19. Stupp R., Dietrich P.-Y., Ostermann Kraljevic S., et al. Promising survival for patients with newly diagnosed glioblastoma multiforme treated with concomitant radiation plus temozolomide followed by adjuvant temozolomide. J Clin Oncol 2002; 20: 1375-1382. 
20. Westphal M., Hilt D.C., Bortey E., et al. A phase 3 trial of local chemotherapy with biodegradable carmustine (BCNU) wafers (Gliadel wafers) in patients with primary malignant glioma. Neurooncology 2003; 5: 79-88.

21. Seiz M., Krafft U., Freyschlag C.F., et al. Long-term adjuvant administration of temozolomide in patients with glioblastoma multiforme: Experience of a single institution. J Cancer Res Clin Oncol 2010; 136: 1691-1695.

22. Friedman H.S., McLendon R.E., Kerby T., et al. DNA mismatch repair and O-6-alkylguanine-DNA alkyltransferase analysis and response to Temodal in newly diagnosed malignant glioma. J Clin Oncol 1998; 16: 3851-3857.

23. Wedge S.R., Porteous J.K., Glaser M.G., et al. In vitro evaluation of temozolomide combined with $\mathrm{X}$-irradiation. Anticancer Drugs 1997; 8: 92-97.

24. Wick W., Wick A., Schulz J.B., et al. Prevention of irradiationinduced glioma cell invasion by temozolomide involves caspase 3 activity and cleavage of focal adhesion kinase. Cancer Res 2002; 62: 1915-1919. 